\title{
Leptin and leptin receptor involvement in cancer development: A study on human primary breast carcinoma
}

\author{
THIERRY JARDÉ ${ }^{1}$, FLORENCE CALDEFIE-CHÉZET ${ }^{1}$, MIREILLE DAMEZ ${ }^{1}$, FLORENCE MISHELLANY ${ }^{2}$, \\ FRÉDÉRIQUE PENAULT-LLORCA ${ }^{2}$, JEAN GUILLOT ${ }^{1}$ and MARIE PAULE VASSON ${ }^{1,3}$ \\ ${ }^{1}$ UFR Pharmacie, Université Clermont 1, EA2416; ${ }^{2}$ Laboratoire d'Anatomopathologie and \\ ${ }^{3}$ Unité de Nutrition, Centre Jean-Perrin, 63001 Clermont-Ferrand Cedex 1, France
}

Received September 4, 2007; Accepted October 19, 2007

\begin{abstract}
Obesity is associated with an increased risk of breast cancer. Leptin, a hormone synthesised essentially by adipose tissue, may be involved in cancer development. We examined the expression of leptin and leptin receptor $(\mathrm{Ob}-\mathrm{R})$ in human primary breast cancer and adjacent non-cancerous tissue. We also analysed their relationships with histological variables such as the oestrogen and progesterone receptors, Ki67 proliferation factor and tumour size. The expressions of leptin and $\mathrm{Ob}-\mathrm{R}$ were investigated by immunohistochemical staining in 35 primary breast cancers and 17 adjacent non-cancerous tissues. Samples and histological features were obtained from the Anti-Cancer Centre. Expressions of leptin and Ob-R were detected in, respectively, 85 and $75 \%$ of the primary breast cancer cases studied. The expression of leptin was significantly correlated with $\mathrm{Ob}-\mathrm{R}$ detection $(\mathrm{p}=0.008)$. In addition, $\mathrm{Ob}-\mathrm{R}$ expression in primary breast carcinoma was positively correlated with oestrogen receptor expression $(\mathrm{p}=0.028)$ and tumour size $(\mathrm{p}=0.045)$ but not with Ki67 or progesterone receptor expressions. However, the expression of leptin showed no statistical correlation with these variables. First, the co-expression of leptin and $\mathrm{Ob}-\mathrm{R}$ in primary breast cancer shows that leptin acts on mammary tumour cells via an autocrine pathway. Second, the co-expression of $\mathrm{Ob}-\mathrm{R}$ and oestrogen receptors suggests a possible interaction between leptin and oestrogen systems to promote breast carcinogenesis. Finally, the fact that Ob-R expression was positively correlated with tumour size may point to a potential role of leptin as a growth factor and of $\mathrm{Ob}-\mathrm{R}$ as a new prognostic factor.
\end{abstract}

Correspondence to: Thierry Jardé, Faculté de Pharmacie, EA2416, Laboratoire de Biochimie, Biologie Moléculaire et Nutrition, 28 place Henri Dunant, B.P. 38, 63001 Clermont-Ferrand Cedex 1, France

E-mail: thierry.jarde@u-clermont1.fr

Key words: breast, breast cancer, ductal carcinoma, leptin, leptin receptor, lobular carcinoma, oestrogen receptor, prognostic, tumour size

\section{Introduction}

Obesity is a major health problem in developed countries; 280,000 US adults die annually of causes related to obesity (1). This pathology is associated with numerous metabolic disorders (endocrine, cardiovascular and gastrointestinal diseases) and is probably involved in the development of various cancers such as colon, prostate and breast cancers (2). It has been clearly demonstrated that obesity is an important risk factor for breast cancer in postmenopausal women $(3,4)$. In addition, being overweight is associated with increased breast cancer recurrence and mortality (5). One of the mechanisms that might explain the relationship between obesity and hormone-dependent breast cancer development is oestrogen overproduction by adipose tissue derived from elevated androgen aromatisation (6). However, adipose tissue is also able to synthesise and secrete many other compounds, termed adipokines, such as leptin, adiponectin, resistin and interleukins (7).

Leptin, a $16 \mathrm{kDa}$ polypeptidic hormone encoded by the obese gene, was first described as a regulator of body weight and energy balance (8). Since its discovery, many other metabolic activities have been demonstrated, leptin interfering with fetal development (9), haematopoiesis (10), reproduction (11) and immunity $(12,13)$. It was initially thought to be synthesised only by adipose tissue (8), but other sources of leptin have been described, including testicles (14), ovaries (15), placenta (16), cartilage and bone cells (17), skeletal muscle (18) and stomach (19). However, adipose tissue remains the main source of leptin in the body. Interestingly, one of factors influencing plasma leptin concentration is adipose tissue mass, circulating leptin levels being positively correlated with body weight and fat mass (20).

Leptin exerts its physiological activity through binding to its receptor, a component part of the class I cytokine receptor family. The leptin receptor (Ob-R) was initially identified in the brain (21), but further work demonstrated its expression in other tissues including immune cells (22), placenta (23), endometrium (24), stomach (25) and lung (26). In addition, Ob-R expression has been detected in pathological tissue, such as acute myeloid leukaemia (27), intracranial (28) and pituitary (29) tumours, hepatocellular carcinoma (30), gastric cancer cells (19) and breast cancer $(31,32)$. 

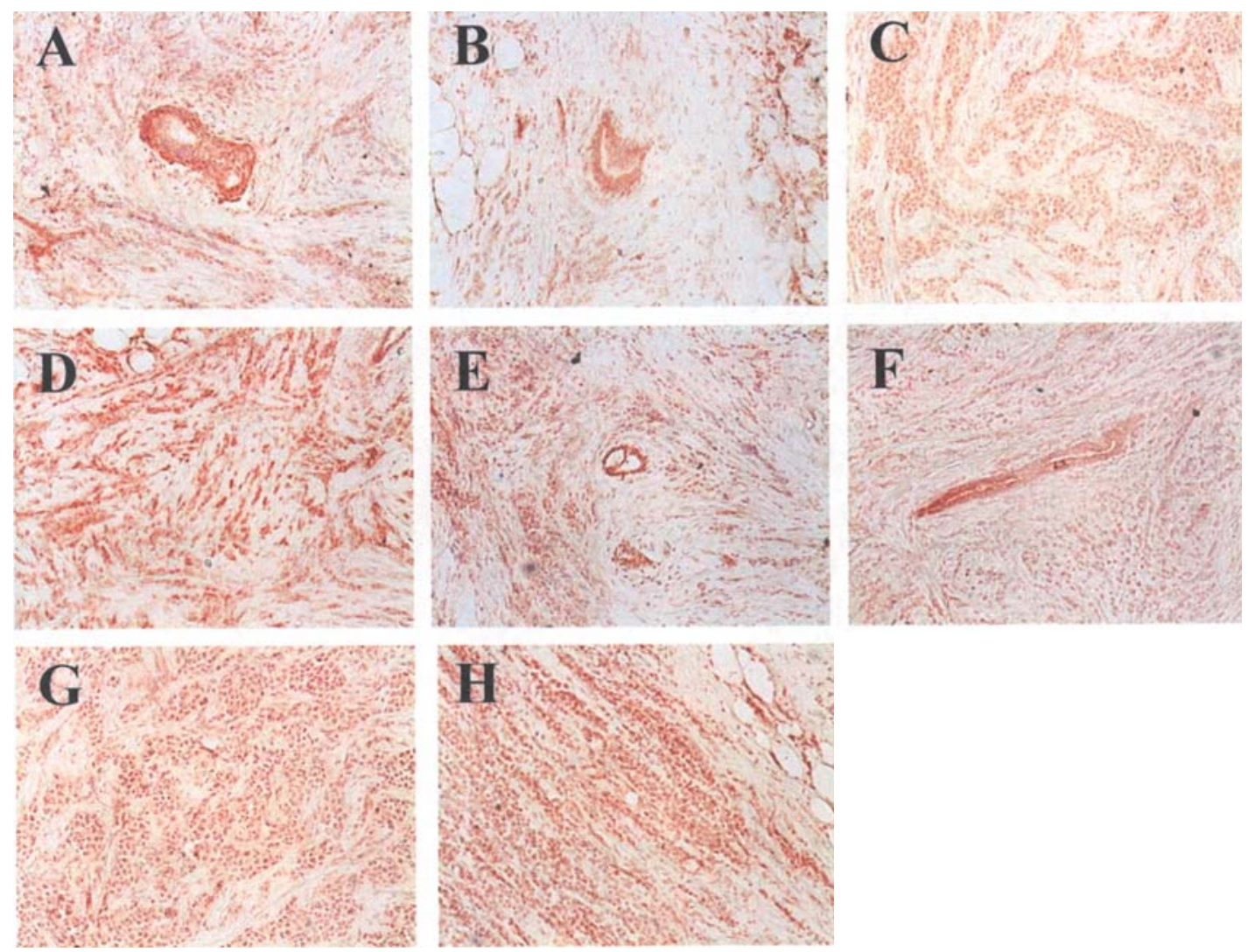

Figure 1. Immunohistochemical detection of leptin receptor (A-D) and leptin (E-H). In these images, leptin receptor detection is observed in normal tissue adjacent to invasive breast ductal carcinoma (A) or invasive lobular carcinoma (B), in invasive breast ductal cancer cells (C) and in invasive breast lobular cancer cells (D). Leptin immunostaining is seen in normal tissue adjacent to invasive breast ductal carcinoma (E) or invasive lobular carcinoma (F), in invasive breast ductal cancer cells $(\mathrm{G})$ and in invasive breast lobular cancer cells (H). Magnification, x80.

Through binding to Ob-R, leptin may influence cancer development. Several authors have found evidence that leptin in vitro promotes angiogenic processes (33), suppresses apoptosis (34) and stimulates proliferation of malignant cell lines of various origins including prostate (35), oesophagus (36) and stomach (37).

In the same way, leptin enhances proliferation of different types of breast lines such as MCF-7, T-47D and ZR-75-1 carcinoma cells (38-40). Exploring tumour biopsies, we previously reported that leptin was expressed by benign breast cells and different grades of mammary ductal lesions (41). We have also reported that leptin is expressed in normal epithelial tissue in the vicinity of breast cancer cells but not in breast epithelial cells in healthy women (41). In addition, leptin expression by peritumoural breast adipose tissue increased in patients with breast cancer (42).

To elucidate the relationship between leptin and breast cancer development, we investigated the pro-carcinogenic potential of leptin by exploring variations in both leptin and $\mathrm{Ob}-\mathrm{R}$ expressions in different grades of ductal and lobular breast lesions by immunohistochemistry. We also analysed the relationships between leptin and its receptor and clinical breast cancer features.

\section{Materials and methods}

All chemicals were purchased from Sigma (Saint-QuentinFallavier, France) except for anti-leptin and anti-Ob-R anti- bodies (R\&D, Abingdon, UK), the avidin/biotin blocking kit, the Vectastain ABC kit, the diaminobenzidine (DAB) substrate and the Vectamount mounting medium (Vector Laboratories, Abcys, Paris, France).

Patients. In total, 35 women aged $30-80$ years, not treated by radiotherapy or chemotherapy, were surgically resected in the Department of Surgery, Centre Jean-Perrin, France. Primary breast cancer tissue samples were immediately frozen, cut into $3 \mu \mathrm{m}$ wide sections, deposited on glass microscope slides and maintained at $-20^{\circ} \mathrm{C}$ until immunohistochemical analysis. This experiment was approved by the local ethics committee.

Tissue classification. The diagnosis was made on alcoholformalin-acetic acid fixed paraffin-embedded tissue sections after haematoxylin-eosin-saffron staining. Routinely, the expression of oestrogen receptors (ER), progesterone receptors (PR) and Ki67 were evaluated and scored as previously described (43). Tissues were classified according to histological subtypes as malignant lesions corresponding to ductal in situ carcinoma $(\mathrm{n}=8)$, lobular in situ carcinoma $(\mathrm{n}=2)$, invasive ductal carcinoma of different grades [grade $1(\mathrm{n}=4)$, $2(n=16)$ or $3(n=8)]$ and invasive lobular carcinoma $(n=7)$. Invasive tumours were evaluated according to the SBR grade classification modified by Elston and Ellis (44).

Immunohistochemistry. The expressions of leptin and $\mathrm{Ob}-\mathrm{R}$ were investigated by immunohistochemical staining using 
Table I. Leptin and leptin receptor expressions in normal tissue adjacent to primary ductal and lobular breast cancer.

\begin{tabular}{lccc}
\hline & \multicolumn{3}{c}{ Normal tissue adjacent to } \\
\cline { 2 - 4 } & $\begin{array}{l}\text { Primary } \\
\text { breast } \\
\text { cancer }\end{array}$ & $\begin{array}{l}\text { Ductal } \\
\text { breast } \\
\text { cancer }\end{array}$ & $\begin{array}{c}\text { Lobular } \\
\text { breast } \\
\text { cancer }\end{array}$ \\
\hline Breast cancer & & & \\
cases & 17 & 12 & 5 \\
$\mathrm{n}$ & & & 4 \\
Leptin receptor & 10 & 6 & 80 \\
$\mathrm{n}^{\mathrm{a}}$ & 60 & 50 & 4 \\
$(\%)$ & & & 8 \\
Leptin & 13 & 75 & 4 \\
$\mathrm{n}^{\mathrm{b}}$ & 75 & & \\
$(\%)$ & & & \\
\hline
\end{tabular}

$\mathrm{n}$, total number of cases studied; $\mathrm{n}^{\mathrm{a}}$, number of cases expressing leptin receptor; $\mathrm{n}^{\mathrm{b}}$, number of cases expressing leptin; (\%), percentage of cases expressing leptin receptor or leptin.

affinity-purified goat polyclonal biotinylated antibodies against leptin and $\mathrm{Ob}-\mathrm{R}$.

Sections were thawed for $1 \mathrm{~h}$ at room temperature before fixing with acetone for $10 \mathrm{~min}$. Non-specific binding sites were blocked using the avidin/biotin kit for $30 \mathrm{~min}$. Slides were then incubated overnight at $4^{\circ} \mathrm{C}$ in a humid chamber with the anti-leptin and anti-Ob-R biotinylated antibodies $(1 \mu \mathrm{g} / \mathrm{ml})$. Endogenous peroxidase activity was inhibited with $0.3 \%$ hydrogen peroxide for $5 \mathrm{~min}$. Visualisation was carried out using a Vectastain $\mathrm{ABC}$ peroxidase-conjugated streptavidine kit for $30 \mathrm{~min}$. The sections were then treated with DAB substrate for $10 \mathrm{~min}$ to give staining. Finally, slides were contrasted using haematoxylin, dehydrated and mounted using the Vectastain mounting medium. For each assay, control samples without the anti-leptin or anti-Ob-R antibody or without the peroxidase revelation kit were used to establish the specificity of the immunohistochemical analysis.

Microscopic examination. Assessment of immunostaining was performed by a pathologist blinded to the clinical data. The expression of leptin and $\mathrm{Ob}-\mathrm{R}$ in cancerous and normal adjacent tissues was classified as negative ( $<5 \%$ labelled cells) or positive ( $\geq 5 \%$ labelled cells). The total percentage of cases with leptin or Ob-R expression was determined.

Statistical analysis. The statistical analysis was performed using Stat View statistical software (SAS Institute). The association between leptin and Ob-R expressions was determined using the $\chi^{2}$ test (with Yates' correction). Relationships between leptin or Ob-R expressions and histological features were analysed using Spearman rank correlation. In this study, because the number of cases was limited, we combined ductal and lobular carcinomas for Spearman rank correlation. Differences with $\mathrm{p}<0.05$ were considered to be statistically significant.

\section{Results}

$O b-R$ and leptin expressions in normal tissue adjacent to breast cancer. The expression of $\mathrm{Ob}-\mathrm{R}$ was examined using a polyclonal antibody recognising the extracellular domain of $\mathrm{Ob}-\mathrm{R}$, similar for all $\mathrm{Ob}-\mathrm{R}$ isoforms.

In normal primary breast cancer tissue, positive $\mathrm{Ob}-\mathrm{R}$ and leptin immunostaining was observed in respectively 60 and $75 \%$ of cases studied (Fig. 1, Table I). More specifically, in invasive ductal carcinomas, normal adjacent tissue expressed Ob-R in 6 out of $12(50 \%)$ cases studied and leptin in 9 out of $12(75 \%)$. Ob-R and leptin were also detected in normal tissue in the vicinity of breast lobular invasive carcinomas in 4 out of $5(80 \%)$ cases studied.

$O b-R$ expression in breast cancer tissue. Positive Ob-R immunostaining was noted in $75 \%$ of primary breast cancer cases (Fig. 1, Table II). In ductal carcinomas, Ob-R was expressed in 6 out of $8(75 \%)$ in situ cases studied. In invasive tissue, Ob-R expression was detected in respectively 75 and $80 \%$ of grade I and II cases and was found in only $50 \%$ of grade III cases. In lobular carcinomas, the percentage of Ob-R expression was $100 \%$ in in situ tissue and $85 \%$ in invasive tissue. In both ductal and lobular breast cancer, Ob-R expression was essentially nuclear $(60 \%$ of cancer cases studied) but was also cytoplasmic ( $40 \%$ of cancer cases studied). The expression of Ob-R was not detected in breast tissue when immunostaining was carried out without biotinylated antibody.

Leptin expression in breast cancer tissue. In ductal and lobular breast carcinomas, positive immunoreactivity for leptin was detected in $85 \%$ of cases studied (Fig. 1, Table II). The expression of leptin was higher in ductal invasive carcinomas (90\% of cases studied) than Ob-R expression (70\% of cases studied), but was similar in in situ ductal carcinomas (75\% of cases studied). In addition, leptin was strongly expressed in all three grades of ductal cancers ( $90 \%$ of cases studied). In lobular carcinomas, the percentage of leptin expression was $100 \%$ in in situ tissue and $70 \%$ in invasive tissue. In contrast to $\mathrm{Ob}-\mathrm{R}$, leptin expression was cytoplasmic and nuclear (in $60 \%$ of cases studied). Leptin immunoreactivity was not detected in control samples when the biotinylated antibody was omitted.

Co-expression of $\mathrm{Ob}-\mathrm{R}$ and leptin in breast cancer. The expression of leptin in breast cancer showed a significant correlation with the expression of Ob-R ( $\mathrm{p}=0.008)$ (Table III). Thus out of 34 carcinomas with positive $\mathrm{Ob}-\mathrm{R}$ expression, 32 also expressed leptin (95\%). By contrast, out of 38 carcinomas with positive leptin immunostaining, 32 expressed Ob-R $(85 \%)$.

Relationships between expressions of leptin or $\mathrm{Ob}-\mathrm{R}$ and histological variables. Ob-R was positively correlated with ER $(\mathrm{p}=0.028, \mathrm{r}=0.264)$ and tumour diameter $(\mathrm{p}=0.045, \mathrm{r}=0.269)$ 
Table II. Leptin and leptin receptor expressions in primary ductal and lobular breast cancer.

\begin{tabular}{|c|c|c|c|c|c|}
\hline \multirow[b]{2}{*}{ Tissue type } & \multirow{2}{*}{$\begin{array}{l}\text { Total no. of } \\
\text { cases studied } \\
n\end{array}$} & \multicolumn{2}{|c|}{ Leptin receptor expression } & \multicolumn{2}{|c|}{ Leptin expression } \\
\hline & & $\mathrm{n}^{\mathrm{a}}$ & $(\%)$ & $\mathrm{n}^{\mathrm{b}}$ & $(\%)$ \\
\hline Primary breast cancer & 35 & 26 & 75 & 30 & 85 \\
\hline Ductal in situ carcinoma & 8 & 6 & 75 & 6 & 75 \\
\hline Invasive ductal carcinoma & 28 & 20 & 70 & 25 & 90 \\
\hline Grade I & 4 & 3 & 75 & 4 & 100 \\
\hline Grade II & 16 & 13 & 80 & 14 & 90 \\
\hline Grade III & 8 & 4 & 50 & 7 & 90 \\
\hline Lobular in situ carcinoma & 2 & 2 & 100 & 2 & 100 \\
\hline Invasive lobular carcinoma & 7 & 6 & 85 & 5 & 70 \\
\hline
\end{tabular}

$\mathrm{n}$, total number of cases studied; $\mathrm{n}^{\mathrm{a}}$, number of cases expressing leptin receptor; $\mathrm{n}^{\mathrm{b}}$, number of cases expressing leptin; (\%), percentage of cases expressing leptin receptor or leptin.

Table III. Relationship between leptin and leptin receptor expressions in in situ and invasive ductal and lobular breast cancer ( $\chi^{2}$ test, $\left.\mathrm{n}=45\right)$.

\begin{tabular}{lccc}
\hline & \multicolumn{2}{c}{ Leptin expression } & \\
\cline { 2 - 3 } & Positive & Negative & p-value \\
\hline $\begin{array}{l}\text { Leptin receptor } \\
\text { expression }\end{array}$ & & & \\
$\quad$ Positive & 32 & 2 & \\
$\quad$ Negative & 6 & 5 & 0.008 \\
\hline
\end{tabular}

Table IV. Correlations between leptin or leptin receptor expressions and histological variables in primary ductal and lobular breast cancer (Spearman test, $\mathrm{n}=35$ ).

\begin{tabular}{lcr}
\hline & p-value & \multicolumn{1}{c}{$\mathrm{r}$} \\
\hline Ob-R, ER & 0.028 & 0.264 \\
Ob-R, PR & 0.293 & 0.028 \\
Ob-R, Ki67 & 0.305 & -0.326 \\
Ob-R, tumour diameter & 0.045 & 0.269 \\
Leptin, ER & 0.154 & 0.106 \\
Leptin, PR & 0.656 & 0.015 \\
Leptin, Ki67 & 0.194 & -0.391 \\
Leptin, tumour diameter & 0.309 & 0.059 \\
\hline
\end{tabular}

(Table IV). However, Ob-R expression showed no significant correlation with Ki67 or PR expressions. The expression of leptin showed no statistically significant correlation with ER, PR or Ki67 expressions, or tumour diameter.

\section{Discussion}

Several lines of evidence have suggested that leptin, a hormone synthesised essentially by adipose tissue, may be involved in cancer development and progression. Numerous studies have demonstrated in vitro that leptin stimulates cancer cell proliferation (35-37), inhibits apoptosis (34) and induces angiogenesis (33). Similar results have been described in breast cancer where leptin stimulates the proliferation of breast cancer cell lines (38-40). In the same way, recent studies have demonstrated that high serum leptin levels are associated with an increased risk of breast cancer (45), and that high expression of $\mathrm{Ob}-\mathrm{Rl}$ and $\mathrm{Ob}-\mathrm{Rs} \mathrm{mRNA}$ in breast cancer tissue predicts poor prognosis (46). However, the role of leptin in breast cancer development is not fully understood.

In human breast cancer tissue, the implication of leptin in mammary carcinogenesis using an immunohistochemical approach has been explored in only a few studies. Initially, O'Brien et al (47) showed leptin expression in the T47D breast cancer cell line. Some authors reported that leptin and $\mathrm{Ob}-\mathrm{R}$ were overexpressed in primary breast cancers, but their conclusions on the relationships between leptin or $\mathrm{Ob}-\mathrm{R}$ and clinicopathological data were conflicting $(31,32)$.

Thus our objective was first to determine whether leptin and $\mathrm{Ob}-\mathrm{R}$ were expressed in primary breast cancer and normal tissue adjacent to breast lesions using frozen tissue sections for immunohistochemical analysis. We chose this procedure because it was as specific as the paraffin-embedded tissue method but more sensitive $(48,49)$. Second, we investigated the relationship between leptin/Ob-R and histological variables, such as oestrogen and progesterone receptors, Ki67 proliferation factor and tumour size.

We have shown that primary ductal and lobular breast cancer strongly express leptin and Ob-R. These data were consistent with the results of Ishikawa et al (31), whereas another study demonstrated that $\mathrm{Ob}-\mathrm{R}$ was poorly expressed in breast cancer cases (41.2\%) (32). A recent report revealed that 
leptin and Ob-R mRNA expressions were detected in $98.7 \%$ and $100 \%$ of mammary tumours, respectively (50). In addition, leptin and Ob-R mRNA have been detected in numerous breast cancer cell lines, such as MCF-7 and T47D $(47,51)$. All these observations confirm that leptin can act not only by endocrine and (or) paracrine action on mammary tumour cells, but also via an autocrine pathway. Additionally, we observed that leptin and $\mathrm{Ob}-\mathrm{R}$ expressions were significantly correlated in breast cancer tissue, in agreement with similar earlier observations $(31,32)$.

A recent hypothesis was that leptin and $\mathrm{Ob}-\mathrm{R}$ might be overexpressed in breast cancer cells, contrary to benign tissue or normal mammary gland adjacent to breast lesions $(31,32)$. In the present study, we observed no such effect, leptin and Ob-R expression levels being comparable in breast cancer and in normal adjacent tissue. Likewise, we recently showed that leptin expression in mammary tumour was similar in benign and normal adjacent tissue (41). However, we originally explored normal breast tissue in healthy women and showed that leptin was not expressed by normal epithelial cells (41). Consequently, we first hypothesised that leptin expression was enhanced in breast cancer compared with normal tissue in healthy women. Second, we suggested that leptin expression in normal tissue adjacent to breast cancer was induced during mammary carcinogenesis. The hypothesis that cancerous tissue may interfere with adjacent tissue was approached by Tessitore et al (42), who showed that leptin mRNA expression was significantly enhanced in adipose tissue adjacent to breast cancer.

Considering the link with histological parameters, we show that $\mathrm{Ob}-\mathrm{R}$ was positively correlated with ER. This finding is consistent with the results of Révillion et al (50), who noted a positive relationship between Ob-R mRNA and ER expression. This was expected since several authors have reported evidence of leptin and oestrogen interactions. Leptin exhibited oestrogen-producing activity by enhancing aromatase mRNA expression, aromatase protein content and its enzymatic activity in MCF-7 breast cancer cells (52). Similar results were obtained in breast human adipose stromal cells where leptin stimulated aromatase activity (53). Also, leptin induced a direct functional activation of ER in MCF-7 cells (54). Reciprocally, the oestrogens were able to modulate the leptin system. In this way, it was demonstrated that $17 ß$-estradiol in vitro increased leptin release and leptin mRNA expression in human adipose tissue $(55,56)$. Also, leptin expression in adipose tissue and serum leptin levels were decreased in ovariectomised rats, and estradiol supplement reversed these effects (57). All these findings suggest that both signalling systems may act via a loop pathway and may contribute to breast carcinogenesis in post-menopausal women or in obesity pathology. Finally, it is interesting to note the interaction between leptin and anti-oestrogen breast cancer treatment. Thus in MCF7 breast cancer cells, leptin interfered with the effects of anti-oestrogen ICI 182,780 by increasing nuclear ER $\alpha$ expression and cell proliferation, decreasing ER $\alpha$ degradation and inducing ER $\alpha$-dependent transcription from oestrogen response element-containing promoters (58). In the same way, recent epidemiological studies reported increased serum leptin levels in women receiving tamoxifen, an anti-oestrogen, as treatment for breast cancer $(59,60)$.
The relationship between leptin and tumour size is still unclear. Using the Spearman test, we showed that Ob-R expression was positively correlated with tumour size. In contrast, Révillion et al (50) found Ob-R mRNA expression to be negatively correlated with tumour size, and other studies revealed no relationship between these variables $(31,32)$. However, leptin, acting via the leptin receptor, was able to stimulate the proliferation of breast cancer cell lines such as MCF-7, T47D and ZR-75-1 (38-40). Using genetically obese leptin receptor-deficient Lepr ${ }^{\mathrm{db}}$ Lepr $^{\mathrm{db}}$ mice, Cleary et al (61) demonstrated that these animals did not develop oncogeneinduced mammary tumours, whereas homozygous Lepr ${ }^{+} \mathrm{Lepr}^{+}$ and heterozygous Lepr ${ }^{+}$Lepr $^{\mathrm{db}}$ lean mice had incidence rates of 69 and $82 \%$ respectively. Similar results had previously been obtained from genetically obese leptin-deficient Lep ${ }^{\mathrm{ob}} \mathrm{Lep}^{\mathrm{ob}}$ mice (62). Another recent study in mice demonstrated that inhibition of leptin signalling using leptin peptide receptor antagonist dramatically reduced the growth of implanted mammary tumours (63). Together, these results point to the potential function of leptin, acting via $\mathrm{Ob}-\mathrm{R}$, as a growth factor for breast cancer, and the possible role of $\mathrm{Ob}-\mathrm{R}$ as a new prognostic factor.

In conclusion, we have shown that leptin and $\mathrm{Ob}-\mathrm{R}$ are strongly co-expressed in both primary breast ductal and lobular cancer, suggesting that leptin acts on breast cancer cells via an autocrine pathway. Also, the co-expression of $\mathrm{Ob}-\mathrm{R}$ and oestrogen receptors in breast cancer may enhance the interaction between leptin and oestrogen systems, contributing to breast cancer development. Finally, high expression levels of $\mathrm{Ob}-\mathrm{R}$ are associated with high tumour size, suggesting that leptin may be a growth factor for breast cancer and that Ob-R may be a future prognostic factor. Acting on leptin signalling may thus offer a new approach to breast cancer prevention and treatment.

\section{Acknowledgements}

This study received financial support from the 'Ligue Contre le Cancer du Puy-de-Dôme', France. Thierry Jardé is supported by fellowship from the Ministry of Research and Technology.

\section{References}

1. Allison DB, Fontaine KR, Manson JE, Stevens J and van Itallie TB: Annual deaths attributable to obesity in the United States. JAMA 282: 1530-1538, 1999.

2. Klein S, Wadden T and Sugerman HJ: AGA technical review on obesity. Gastroenterology 123: 882-932, 2002.

3. Chu SY, Lee NC, Wingo PA, Senie RT, Greenberg RS and Peterson HB: The relationship between body mass and breast cancer among women enrolled in the Cancer and Steroid Hormone Study. J Clin Epidemiol 44: 1197-1206, 1991.

4. Lahmann PH, Hoffmann K, Allen N, et al: Body size and breast cancer risk: findings from the European Prospective Investigation into Cancer And Nutrition (EPIC). Int J Cancer 111: 762-771, 2004.

5. Chlebowski RT, Aiello E and McTiernan A: Weight loss in breast cancer patient management. J Clin Oncol 20: 1128-1143, 2002.

6. Key TJ, Allen NE, Verkasalo PK and Banks E: Energy balance and cancer: the role of sex hormones. Proc Nutr Soc 60: 81-89, 2001 .

7. Dizdar O and Alyamac E: Obesity: an endocrine tumor? Med Hypotheses 63: 790-792, 2004.

8. Zhang Y, Proenca R, Maffei M, Barone M, Leopold L and Friedman J: Positional cloning of the mouse obese gene and its human homologue. Nature 372: 425-432, 1994. 
9. Hoggard N, Haggarty P, Thomas L and Lea RG: Leptin expression in placental and fetal tissues: does leptin have a functional role? Biochem Soc Trans 29: 57-63, 2001.

10. Gainsford T, Willson TA, Metcalf D, et al: Leptin can induce proliferation, differentiation, and functional activation of hemopoietic cells. Proc Natl Acad Sci USA 93: 14564-14568, 1996.

11. Mounzih K, Lu R and Chehab FF: Leptin treatment rescues the sterility of genetically obese ob/ob males. Endocrinology 138: 1190-1193, 1997.

12. Caldefie-Chezet F, Poulin A and Vasson MP: Leptin regulates functional capacities of polymorphonuclear neutrophils. Free Radic Res 37: 809-814, 2003.

13. Caldefie-Chezet F, Poulin A, Farges MC, Walrand S and Vasson MP: Implication of leptin in the non-specific immune response of stressed rats. Eur J Clin Invest 36: 668-669, 2006.

14. Soyupek S, Armagan A, Serel TA, Hoscan MB, Perk H, Karaoz E and Candir O: Leptin expression in the testicular tissue of fertile and infertile men. Arch Androl 51: 239-246, 2005.

15. Loffler S, Aust G, Kohler U and Spanel-Borowski K: Evidence of leptin expression in normal and polycystic human ovaries. Mol Hum Reprod 7: 1143-1149, 2001.

16. Masuzaki H, Ogawa Y, Sagawa N, et al: Non-adipose tissue production of leptin: leptin as a novel placenta-derived hormones in humans. Nat Med 3: 1029-1033, 1997.

17. Morroni M, De Matteis R, Palumbo C, et al: In vivo leptin expression in cartilage and bone cells of growing rats and adult humans. J Anat 205: 291-296, 2004.

18. Solberg R, Aas V, Thoresen GH, Kase ET, Drevon CA, Rustan AC and Reseland JE: Leptin expression in human primary skeletal muscle cells is reduced during differentiation. J Cell Biochem 96: 89-96, 2005.

19. Mix H, Widjaja A, Jandl O, et al: Expression of leptin and leptin receptor isoforms in the human stomach. Gut 47: 481-486, 2000.

20. Somasundar P, McFadden DW, Hileman SM and Vona-Davis L: Leptin is a growth factor in cancer. J Surg Res 116: 337-349, 2004

21. Tartaglia LA, Dembski M, Weng X, et al: Identification and expression cloning of a leptin receptor, OB-R. Cell 83: 1263-1271, 1995.

22. Caldefie-Chezet F, Poulin A, Tridon A, Sion B and Vasson MP: Leptin: a potential regulator of polymorphonuclear neutrophil bactericidal action? J Leukoc Biol 69: 414-418, 2001.

23. Ebenbichler CF, Kaser S, Laimer M, Wolf HJ, Patsch JR and Illsley NP: Polar expression and phosphorylation of human leptin receptor isoforms in paired, syncytial, microvillous and basal membranes from human term placenta. Placenta 23: 516-521, 2002.

24. Kitawaki J, Koshiba H, Ishihara H, Kusuki I, Tsukamoto K and Honjo $\mathrm{H}$ : Expression of leptin receptor in human endometrium and fluctuation during the menstrual cycle. J Clin Endocrinol Metab 85: 1946-1950, 2000.

25. Breidert M, Miehlke S, Glasow A, et al: Leptin and its receptor in normal human gastric mucosa and in Helicobacter pyloriassociated gastritis. Scand J Gastroenterol 34: 954-961, 1999.

26. Tsuchiya T, Shimizu H, Horie T and Mori M: Expression of leptin receptor in lung: leptin as a growth factor. Eur J Pharmacol 365: 273-279, 1999.

27. Konopleva M, Mikhail A, Estrov Z, et al: Expression and function of leptin receptor isoforms in myeloid leukemia and myelodysplastic syndromes: proliferative and anti-apoptotic activities. Blood 93: 1668-1676, 1999.

28. Knerr I, Schuster S, Nomikos P, et al: Gene expression of adrenomedullin, leptin, their receptors and neuropeptide $\mathrm{Y}$ in hormone-secreting and non-functioning pituitary adenomas, meningiomas and malignant intracranial tumours in humans. Neuropathol Appl Neurobiol 27: 215-222, 2001.

29. Shimon I, Yan X, Magoffin DA, Friedman TC and Melmed S: Intact leptin receptor is selectively expressed in human fetal pituitary and pituitary adenomas and signals human fetal pituitary growth hormone secretion. J Clin Endocrinol Metab 83: 4059-4064, 1998

30. Wang XJ, Yuan SL, Lu Q, Lu YR, Zhang J, Liu Y and Wang WD: Potential involvement of leptin in carcinogenesis of hepatocellular carcinoma. World J Gastroenterol 10: 2478-2481, 2004.

31. Ishikawa M, Kitayama J and Nagawa $H$ : Enhanced expression of leptin and leptin receptor (OB-R) in human breast cancer. Clin Cancer Res 10: 4325-4331, 2004.

32. Garofalo C, Koda M, Cascio S, et al: Increased expression of leptin and the leptin receptor as a marker of breast cancer progression: possible role of obesity-related stimuli. Clin Cancer Res 12: 1447-1453, 2006.
33. Bouloumie A, Drexler HC, Lafontan M and Busse R: Leptin, the product of $\mathrm{Ob}$ gene, promotes angiogenesis. Circ Res 83: 1059-1066, 1998

34. Rouet-Benzineb P, Aparicio T, Guilmeau S, Pouzet C, Descatoire V, Buyse M and Bado A: Leptin counteracts sodium butyrate-induced apoptosis in human colon cancer HT-29 cells via NF-kappaB signaling. J Biol Chem 279: 16495-16502, 2004.

35. Onuma M, Bub JD, Rummel TL and Iwamoto Y: Prostate cancer cell-adipocyte interaction: leptin mediates androgenindependent prostate cancer cell proliferation through c-Jun NH2-terminal kinase. J Biol Chem 278: 42660-42667, 2003

36. Somasundar P, Riggs D, Jackson B, Vona-Davis L and McFadden DW: Leptin stimulates esophageal adenocarcinoma growth by non-apoptotic mechanisms. Am J Surg 186: 575-578, 2003

37. Pai R, Lin C, Tran T and Tarnawski A: Leptin activates STAT and ERK2 pathways and induces gastric cancer cell proliferation. Biochem Biophys Res Commun 331: 984-992, 2005.

38. Dieudonne MN, Machinal-Quelin F, Serazin-Leroy V, Leneveu MC, Pecquery R and Giudicelli Y: Leptin mediates a proliferative response in human MCF7 breast cancer cells. Biochem Biophys Res Commun 293: 622-628, 2002.

39. Hu X, Juneja SC, Maihle NJ and Cleary MP: Leptin: a growth factor in normal and malignant breast cells and for normal mammary gland development. J Natl Cancer Inst 94: 1704-1711, 2002.

40. Chen C, Chang YC, Liu CL, Chang KJ and Guo IC: Leptininduced growth of human ZR-75-1 breast cancer cells is associated with up-regulation of cyclin D1 and c-Myc and down-regulation of tumor suppressor p53 and p21WAF1/CIP1. Breast Cancer Res Treat 98: 121-132, 2006.

41. Caldefie-Chezet F, Damez M, De Latour M, et al: Leptin: a proliferative factor for breast cancer? Study on human ductal carcinoma. Biochem Biophys Res Commun 334: 737-741, 2005.

42. Tessitore L, Vizio B, Jenkins O, et al: Leptin expression in colorectal and breast cancer patients. Int J Mol Med 5: 421-426, 2000.

43. Penault-Llorca F, Cayre A, Bouchet MF, et al: Induction chemotherapy for breast carcinoma: predictive markers and relation with outcome. Int J Oncol 22: 1319-1325, 2003.

44. Elston CW and Ellis IO: Pathological prognostic factors in breast cancer. I. The value of histological grade in breast cancer: experience from a large study with long-term follow-up. Histopathology 19: 403-410, 1991.

45. Chen DC, Chung YF, Yeh YT, et al: Serum adiponectin and leptin levels in Taiwanese breast cancer patients. Cancer Lett 237: 109-114, 2005.

46. Miyoshi Y, Funahashi T, Tanaka S, Taguchi T, Tamaki Y, Shimomura I and Noguchi S: High expression of leptin receptor mRNA in breast cancer tissue predicts poor prognosis for patients with high, but not low, serum leptin levels. Int J Cancer 118: 1414-1419, 2006.

47. O'Brien SN, Welter BH and Price TM: Presence of leptin in breast cell lines and breast tumors. Biochem Biophys Res Commun 259: 695-698, 1999.

48. Onetti-Muda A, Crescenzi A, Pujia N, Faraggiana T and Marinozzi V: Demonstration of oestrogen and progesterone receptors in freeze-dried, paraffin-embedded sections of breast cancer. Histopathology 18: 511-516, 1991

49. Cohen C, Unger ER, Sgoutas D, Bradley N and Chenggis M: Automated immunohistochemical estrogen receptor in fixed embedded breast carcinomas. Comparison with manual immunohistochemistry on frozen tissues. Am J Clin Pathol 92: 669-672, 1989.

50. Révillion F, Charlier M, Lhotellier V, et al: Messenger RNA expression of leptin and leptin receptors and their prognostic value in 322 human primary breast cancers. Clin Cancer Res 12: 2088-2094, 2006.

51. Yin N, Wang D, Zhang H, et al: Molecular mechanisms involved in the growth stimulation of breast cancer cells by leptin. Cancer Res 64: 5870-5875, 2004.

52. Catalano S, Marsico S, Giordano C, Mauro L, Rizza P, Panno ML and Ando S: Leptin enhances, via AP-1, expression of aromatase in the MCF-7 cell line. J Biol Chem 278: 28668-28676, 2003

53. Magoffin DA, Weitsman SR, Aagarwal SK and Jakimiuk AJ: Leptin regulation of aromatase activity in adipose stromal cells from regularly cycling women. Ginekol Pol 70: 1-7, 1999. 
54. Catalano S, Mauro L, Marsico S, et al: Leptin induces, via ERK1/ERK2 signal, functional activation of estrogen receptor alpha in MCF-7 cells. J Biol Chem 279: 19908-19915, 2004.

55. Casabiell X, Pineiro V, Peino R, et al: Gender differences in both spontaneous and stimulated leptin secretion by human omental adipose tissue in vitro: dexamethasone and estradiol stimulate leptin release in women, but not in men. J Clin Endocrinol Metab 83: 2149-2155, 1998.

56. Machinal-Quelin F, Dieudonne MN, Pecquery R, Leneveu MC and Giudicelli Y: Direct in vitro effects of androgens and estrogens on ob gene expression and leptin secretion in human adipose tissue. Endocrine 18: 179-184, 2002.

57. Shimizu H, Shimomura Y, Nakanishi Y, Futawatari T, Ohtani K, Sato $\mathrm{N}$ and Mori $\mathrm{M}$ : Estrogen increases in vivo leptin production in rats and human subjects. J Endocrinol 154: 285-292, 1997.

58. Garofalo C, Sisci D and Surmacz E: Leptin interferes with the effects of the antiestrogen ICI 182,780 in MCF-7 breast cancer cells. Clin Cancer Res 10: 6466-6475, 2004.
59. Marttunen MB, Andersson S, Hietanen P, et al: Antiestrogenic tamoxifen and toremifene increase serum leptin levels in postmenopausal breast cancer patients. Maturitas 35: 175-179, 2000.

60. Ozet A, Arpaci F, Yilmaz MI, et al: Effects of tamoxifen on the serum leptin level in patients with breast cancer. Jpn J Clin Oncol 31: 424-427, 2001.

61. Cleary MP, Juneja SC, Phillips FC, Hu X, Grande JP and Maihle NJ: Leptin receptor-deficient MMTV-TGF-alpha/ Lepr $(d b) \operatorname{Lepr}(d b)$ female mice do not develop oncogeneinduced mammary tumors. Exp Biol Med 229: 182-193, 2004.

62. Cleary MP, Phillips FC, Getzin SC, et al: Genetically obese MMTV-TGF-alpha/Lep(ob)Lep(ob) female mice do not develop mammary tumors. Breast Cancer Res Treat 77: 205-215, 2003.

63. Gonzalez RR, Cherfils S, Escobar M, et al: Leptin signaling promotes the growth of mammary tumors and increases the expression of vascular endothelial growth factor (VEGF) and its receptor type two (VEGF-R2). J Biol Chem 281: 26320-26328, 2006. 